\title{
MEDICAL ASPECTS OF VIOLATION OF THE RIGHT TO LIFE IN THE CONTEXT OF THE EUROPEN COURT OF HUMAN RIGHTS CASE LAW
}

DOI: $10.36740 /$ WLek202012214

\author{
Olga M.Voloshchenko, Olena A. Ustymenko \\ V.N. KARAZIN KHARKIV NATIONAL UNIVERSITY, KHARKIV, UKRAINE
}

\begin{abstract}
The aim: The purpose of the paper is to raise awareness of the medical services subjects in the issues of establishment of the relationship between their activities and harm to patients, analysis of the case law of the ECHR and provision of practical recommendations for the prevention of violations of Art. 2 of the Convention with subsequent compensation for non-pecuniary and pecuniary damage.

Materials and methods: The authors used the judgements of the European Court of Human Rights (ECHR) on medical research, international regulatory acts, publications of scholars in the field of medical law and legal doctrine in terms of liability of medical services providers for the violation of Art. 2 of the Convention.

Conclusions: Aiming to ensure proper legal protection of the rights and legitimate interests of subjects of medical care, the authors have developed recommendations on how to prevent cases of violation of the right to life during the provision of medical services.
\end{abstract}

KEY WORDS: balance of doctors' and patients' interests, the "open door" mode, patient

\section{INTRODUCTION}

Art. 2 of the Convention for the Protection of Human Rights and Fundamental Freedoms (hereinafter - the Convention) defines the everyone's right to life shall be protected by law. [1] The inviolability of the right to life is also guaranteed in Article 3 of the Universal Declaration of Human Rights, which states that "everyone has the right to life" [2]. At the same time, the list of actions that are defined in the Convention and are admissible in matters of deprivation of life and are not qualified as a violation of this article creates a protective "barrier" for persons who commit acts of self-defense against violence or oppose illegal actions of persons who are detained, etc. This approach of lawmakers gives grounds to claim that the only group of persons who can be released from liability (subject to the condition of the exclusively necessary use of force) for violation of the right to life in the performance of professional duties are law enforcement officials.

From the point of view of legal risks, the provision of medical services is the most vulnerable in terms of ensuring proper conditions for the observance of the right to life of a human in the provision of qualified medical care. This thesis is due to the fact that human rights in the field of health complement bioethics, but at the same time cover a set of generally accepted standards and procedures that allow to draw conclusions about violations in the context of health care and provide protection against such violations [3, p.1.1]. the Harmonization of national legislation with European Union standards is among the most common ways to improve the legal regulation of health care in the member states of the European Union. The implementation of international law into domestic law is a constant practice in Great Britain, Bulgaria, Poland, etc.

It is beyond argument that the adaptation of national legislation to "uniform" standards is made in such a way as to provide leverage to influence the behavior of the subjects of relations devoid of ambiguity in the interpretation of their application. This approach is self-sufficient in terms of ensuring the interests of the state as a subject of regulation of social relations. However, compliance with the requirement to balance the interests of patient and doctor is possible only when the analysis of judicial practice for the effectiveness of a rule of law that governs the relationships in the provision of medical services.

\section{THE AIM}

The purpose of the paper is to raise awareness of the medical services subjects in the issues of establishment of the relationship between their activities and harm to patients, analysis of the case law of the ECHR and provision of practical recommendations for the prevention of violations of Art. 2 of the Convention with subsequent compensation for non-pecuniary and pecuniary damage.

\section{MATERIALS AND METHODS}

The paper is devoted to the analysis of the ECHR case law and legal doctrine on liability of medical services provid- 
ers for the violation of Art. 2 of the Convention during the performance of professional duties. We used the dialectical method to formulate conclusions regarding the understanding of the content of Art. 2 of the Convention in the context of ECHR decisions; the analytical method was used in determining the trends of the case law of the ECHR on the outlined subject; the method of synthesis was used to create conclusions and recommendations for the prevention of violations of Art. 2 of the Convention.

\section{REVIEW AND DISCUSSION}

The provisions of the Convention are general in nature. Their significance in all the variety of meaningful manifestations is revealed in the case law of the European Court of Human Rights (hereinafter - the ECHR). According to Art. 32 of the Convention, the ECHR is the authority empowered to interpret the provisions of the Convention and its Protocols. And specifically, this international judicial institution determines the correct version of the understanding and content of the norms and legal concepts enshrined in the Convention. [4, p.5] Thus, the decisions of the ECHR as an international judicial body whose jurisdiction covers all member states of the Council of Europe are binding and unprecedentedly oblige the respondent State to comply with such a decision.

Analytical activities with the subsequent development of appropriate legal recommendations are useful in the field of private and public medical assistance. In particular, analytical methods will provide an opportunity to outline a range of additional criteria and standards with their subsequent enshrinement in local acts regulating the activities of employees of medical institutions. Such measures are preventive in nature and are designed to prevent litigations aimed at recognition of the activities of a doctor (hospital) as such that appeared to be a result of a violation of patients' rights.

The Report of the ECHR in 2019 confirmed the existence of deficiencies in the mechanisms of medical care and the functioning of medical institutions, which led to a violation of the right to life of patients, in the cases of violations of Art. 2 of the Convention. [5] Among the reasons for the existence of the outlined issues, case law determines the violation of the balance of mutual interests of doctor and patient. This introduction of doctrinal views seems positive, as it is taken into account in further ways to address the causes of violations of the right to life in the provision of medical care.

G. Lianning noted that in modern conditions of development and improvement of the health care system, doctors and patients should cooperate to make joint decisions on diagnosis and treatment [6]. The interaction of the patient and the doctor is a key factor not only in making a correct diagnosis and carrying out of further treatment but also in recognizing the actions of doctors as such that violate the right to life in the context of ensuring the mutual interests of these parties. V. Flis believes that the liability of doctors and medical institutions is thus based solely on negligence and on each of its degrees. In case of the civil liability of a doctor, unlike in criminal liability, slight negligence, which is assessed as an objective category, with objective criteria for negligence, is sufficient.[7, p.74]
Therefore, compliance with mutual interests and taking into account case law will provide an opportunity to prevent the commission of acts of medical negligence or error, and so on.

Given the practical significance, it is worth considering the position of the ECHR in the decision of June 27, 2017 "Gard and Others v. The United Kingdom". In this case the ECHR considered the aspect of compliance with the positive obligations under Art. 2 (right to life) of the Convention and concluded that the application for the decision to cancel the artificial maintenance of vital functions of a child suffering from a fatal genetic disease was unacceptable. $[8$, p.51]

The complexity of the case was that the applicants complained about the hospital's actions to block access to artificial maintenance of patients' vital functions. An additional factor of complexity was the fact that the dispute concerned an infant suffering from a fatal genetic disease. The applicants, in turn, demanded from the hospital to allow undergoing experimental treatment in the United States. Instead, the domestic courts concluded that the cessation of the infant's artificial maintenance could be lawful, as the child could suffer serious damage if the suffering from the symptoms of the disease were continued without the prospect of positive dynamics from the experimental treatment.

It is noteworthy that the practice of the ECHR in these categories of cases on the interests of patients and hospitals shall meet the following three criteria: 1 . The existence of an appropriate legal basis consistent with the provisions of the Council of Europe Convention on Human Rights (on the issue of experimental treatment abroad); 2. Taking into account the wishes previously expressed by the patient, close relatives and medical staff; 3 . The possibility of appealing against the actions of employees of the medical institution in court.

In the case above, the patient was an infant who was not able to express his wishes due to mental development. It should be noted that the activities of the medical institution fully met the requirement for the second criterion, namely:

A) The child's parents were involved and their opinion was taken into account when making decisions on providing medical care to the child; among others, the possibility to provide instructions to their expert in the field of qualified medical care was ensured.

B) The court provided evidence of the involvement of a group of specialists to advise and make a collective decision on effective treatments and the possibility of providing experimental treatment abroad.

Such approach made it impossible to recognize the involvement of a medical institution in the violation of the right to life on grounds of non-compliance with the requirements of the patient's (patient representatives) involvement and taking into account their will in the treatment process.

Another decision of the European Court of Human Rights of March 28, 2017, in the case of Fernandes De Oliveira v. Portugal is interesting in terms of justifying the admission of guilt of a medical institution in terms of violation of the right to life. This case can be considered exemplary in meeting mutual interests of the patient and the hospital, complicated by the specifics of the treatment regimen. According to the circumstances of the case, the applicant's son was taken to a 
state psychiatric hospital for treatment after a suicide attempt. Previously, the young man had already been hospitalized several times in the same hospital due to his mental health (on the grounds of unsuccessful suicide attempts). In view of the above, the ECHR noted that the hospital staff had reasons to assume that he could try to commit suicide again. Besides, it was possible in the view of his diagnosis to foresee another attempt to escape with the possibility of fatal consequence since he had escaped from the hospital earlier. [9]

Thus, the ECHR obliges employees of the medical institution to take actions based on anticipation provided that the patient's actions are systematic. By this case the ECHR explained that in the categories of such actions, for example, medical staff should more often carry out control measures to ensure the presence of the patient in the hospital. The court also noted that one of the causes of death for the patient was the ineffectiveness of the mechanism of the medical institution's response to the absence of the missing patient. In particular, it was noted that in the case of a mentally ill patient who had recently attempted suicide and was prone to escape, hospital staff should have been expected to take safeguarding measures on a more regular basis to ensure that he did not leave the hospital. [9]

The ECHR also noted that there were increased risks in this case due to the "open door" regime. The possibility of treating mentally ill patients (according to the indications) without complete isolation from society and with access to public places is positive in terms of the dynamics of recovery. However, this type of treatment does not release the subject of medical care from the obligation to protect mentally ill patients from the risks, which they create for themselves.

It is also specific that in this situation, a recommendation is given referring to the need to establish a balance between the responsibilities of the medical institution according to Art. 2 of the Convention during "open door" treatment regimen and the patient's personal needs through enhanced surveillance of suicidal patients. The indicated warning should be applied by medical institutions regardless of the method of placing the patient in a medical institution. That is, when ensuring a balance of interests, it is not necessary to distinguish between voluntary and involuntary hospitalization. The level of control measures for this category of patients should be based on the criteria of personal characteristics of the patient taking into account the systematic implementation of suicide attempts.

Another exemplary case is Lopes De Sousa Fernandes v. Portugal regarding violation of the requirements of mutual patient-doctor interests, which was qualified as medical negligence on the side of the physician in the decision of December 19, 2017 [10]. As a result of the surgery for the removal of nasal polyps, the applicant's husband suffered from bacterial meningitis, which was detected two days after his discharge. As a result of the repeated treatment, the man was hospitalized and underwent medical interventions as part of medical care. This happened several times, as a result of which the man died from the effects of septicemia caused by peritonitis and perforation of the internal cavity. Following the examination of the case file, the ECHR provided a distinction between the qualification of doctors' actions and the distinction between cases concerning the negligence of doctors and the case of denial of access to emergency rescue care.

In order for a case to fall into the latter category, the following factors must be considered together: 1 . The actions and omissions of health professionals should go beyond the simple error or negligence of doctors. J. Anderson notes that health workers, in breach of their professional responsibilities, refuse emergency care, even though they are fully aware that a person's life is in danger if treatment is not provided. [11] The concept of awareness implies a set of factors that include both the qualifications of the doctor and experience in providing similar medical care and the severity (stage) of the disease.

The next criterion is the dysfunction of hospital services. 2. The dysfunction should be objective and recognizable as systematic or structural, and should not include cases where something could be dysfunctional in the sense of misconduct of a person or functioning. [10] In this criterion, the ECHR classifies two actions of the subjects of medical care, which are covered by signs of systematic nature and misconduct.

Misconduct of a person (doctor) must have a subjective basis, i.e. it should be based on actions caused by personal factors that lead to the provision of low-quality services. Systematicity is a criterion that involves the performance of duties by an employee of a medical institution in a certain order by analogy with previous cases of qualified care in such cases.

Misconduct of a person implies a situation where a health professional provides qualified care in violation of the requirements of clinical protocols, which should be based on the regulatory standards of such care. In this situation, the doctor is legally liable if the patient is damaged or injured due to the fact that the subject of medical services has deviated from the quality of care that is usually expected in similar situations. [12] In the context of misconduct, the inaction of doctors in providing medical care is also recognized. In the decision of the ECHR of July 18, 2017, in the case of Nina Kutsenko v. Ukraine, inaction is equaled to the category of "refusal to provide medical care" [13], except in cases of such a refusal by a doctor on legal grounds.

It is noteworthy that the actions that qualify the ECHR as wrongful acts of a medical professional in most cases are associated with consequences that entail violations not only of Article 2 of the Convention, but also of Art. 3.

To continue the previous thesis (in case of incorrect actions of a medical worker) it is necessary to pay attention to the decision of the European Court of Human Rights of 15.05.2012 in the case of Kaverzin v. Ukraine.[14] The applicant's total loss of sight and his first group of disabilities were equated with the consequences of the doctors' inaction and a violation of Article 3 of the Convention. The same position is supported by the decision of 08.09.2011 in the case of the European Court of Human Rights "Oshurko v. Ukraine". The same position is supported by the decision of 08.09.2011 in the case of Oshurko v. Ukraine, in which the provision of inadequate medical care was understood in the context of doctors' actions to provide unqualified treatment ("no systemic treatment") and refusal to provide inpatient treatment.[15]

3. There must be a link between the dysfunction of the healthcare provider and the harm caused to the patient. It 
is important to note that in civil proceedings the burden of proving the existence of such a connection rests with the persons who address with the claim about compensation of the harm caused.

4. The last combined criterion is the lack of statutory prescription of the implementation of the activities of the medical services subjects according to their functional compliance.

The case Lopes De Sousa Fernandes v. Portugal is exemplary in terms of the necessity of imposing responsibilities on the state on fixing of procedures for the provision of medical services by hospitals at the legislative level. In case of absence of such fixation, medical workers of medical institutions are not responsible for violation of Art. 2 of the Convention subject to the comprehensive availability of the above criteria.

\section{CONCLUSIONS}

1. In view of the above, it is stated that the key factor in providing quality medical care is the mutual cooperation of doctor and patient. Moreover, the effectiveness of achieving a positive result in certain categories of diseases is possible through the application by the medical institution of the so-called preventive measures that should be applied by the medical institution to prevent violations of the right to life of patients.

2. In the field of providing treatment to mentally ill patients it is recommended to take into account the following factors (in order to prevent the recognition of the actions of medical staff as violating the patient's right to life): a) history of mental illness; $b$ ) the severity of mental illness; c) previous attempts to commit suicide or self-harm; d) suicidal thoughts or threats. In the presence of at least one of the above circumstances, three precautionary measures must be taken: daily schedule with control of the patient's presence; emergency procedure (in case of inpatient treatment in institutions with "open" doors, it is recommended to use a "restrictive procedure").

3. A set of the following factors should be considered as a criteria for distinguishing the refusal of emergency medical care from medical negligence: the behavior of a health professional, which is not qualified as medical negligence or error; dysfunction of hospital services, the causal link between damage and dysfunction; lack of statutory prescription of requirements for the functioning of the medical institution at the regulatory level.

\section{REFERENCES}

1 Convention for the Protection of Human Rights and Fundamental Freedoms dates 4 November 1950. Available from: https://www.echr. coe.int/Documents/Convention_ENG.pdf [reviewed: 2020.08.06].

2. Universal Declaration of Human Right dates 10 December 1948. Available from: https://www.ohchr.org/EN/UDHR/Pages/UDHRIndex. aspx [reviewed: 2020.08.06].

3. I.Y.Senyta Ohoronazdorovya I prava lyudunu: resyrsnuy posibnuk. [Health and Human Rights: Aresource Guide].2015. Available from: http:// medicallaw.org.ua/fileadmin/user_upload/PDF/\%D1\%80\%D0\% B5\%D1\%81\%D0\%BE\%D1\%80\%D1\%81/\%D0\%A0\%D0\%B5\%D1\% 81\%D0\%BE\%D1\%80\%D1\%81_\%D1\%80\%D0\%BE\%D0\%B7\%D0\%B 4\%D1\%96\%D0\%BB_1.pdf [reviewed: 2020.08.07] (Ua).
4. I.Y.Senyta Pravovi pozucii Yevropeskogo sudu u sferi ohorony zdorovya [Legal positions of the European Court of Health] Harkiv: Faktor. 2020. 192 p. (Ua).

5. Annual report Europian Court of Human Rights 2019. Available from: https://www.echr.com.ua/wp-content/uploads/2020/06/ Annual_report_2019_ENG.pdf [reviewed: 2020.08.07].

6. Jennifer Leaning. Human rights and medical education. Boston Medical Journal.1997; 315:1390. doi: 10.1136/bmj.315.7120.1390

7. Flis V., No Fault Compensation for Medical Injuries. Medicine, Law \& Society. 2016;9(2):73-84. doi: 10.18690/24637955.9.2.73-84(2016).

8. 0.M. Drozdov, O.V. Drozdova Pravovi pozycii Yevropejskogo sydy z prav lyudunu: analituchnuy oglyad [Legal positions of the European Court of Human Rights: ananalytical review] Harkiv: Faktor. 2018.624p. (Ua).

9. Case of Fernandes de Olivera v. Portugal. Available from: https:// ehrac.org.uk/resources/fernandes-de-oliveira-v-portugal/ [reviewed: 2020.08.07].

10. Case of Lopes DeSousa Fernandes v. Portugal. Available from: http:// hudoc.echr.coe.int/eng?i=001-179556 [reviewed: 2020.08.07].

11. Anderson J.G, Abrahamson K., Your Health Care May Kill You: Medical Errors. Studies in Health Technology and Informatics. 2017; 234:13-17.

12. Nordqvist C. Medical malprac tice: What does it involve? MedicalNewsToday, 5 April 2017. Available from: https://www. medicalnewstoday.com/articles/248175.php [reviewed:2020.08.07].

13. Case of Nina Kutsenko v. Ukraine Available from: hudoc.echr.coe.int/ eng\#\{\%22itemid\%22:[\%22001-175471\%22]\} [reviewed:2020.08.07].

14. Case of Kaverzin v. Ukraine. Available from: http://hudoc.echr.coe.int/ rus? $\mathrm{i}=001-110895$ [reviewed: 2020.08.15].

15. Case of Oshurkov v. Ukraine. Available from: https://hudoc.echr.coe.int/ rus\#\{\%22itemid\%22:[\%22001-204037\%22]\} [reviewed:2020.08.07].

\section{ORCID and contributionship:}

Olha M. Voloshchenko: 0000-0003-4780-4594 A,B,D,E,F

Olena A. Ustymenko: 0000-0002-1861-8306 A,B,D,E,F

\section{Conflict of interest:}

The Authors declare no conflict of interest.

\section{CORRESPONDING AUTHOR}

Olha M. Voloshchenko

V.N. Karazin Kharkiv National University

Sq.Svobody, 4, Kharkiv, 61000, Ukraine

tel: +380688894524

e-mail:ovolosenk0003@gmail.com

Received: 30.08 .2020

Accepted: 27.11 .2020

A - Work concept and design, B - Data collection and analysis, C - Responsibility for statistical analysis,

D-Writing the article, $\mathbf{E}$-Critical review, $\mathbf{F}$ - Final approval of the article 